\title{
RANCANG BANGUN APLIKASI PENGELOLAAN ORGANISASI EKSTRAKURIKULER (STUDI KASUS: AMIK MBP MEDAN)
}

\author{
${ }^{1}$ Marice Hotnauli Simbolon, ${ }^{2}$ Roberto Kaban \\ Politeknik Poliprofesi Medan, Jl. Sei Batanghari No. 3-4 Medan, Telp. 061-8447629 \\ Jurusan ${ }^{1}$ Teknik Informatika ; ${ }^{2}$ Manajemen Informatika \\ e-mail: ${ }^{1}$ simbolonice@gmail.com; ${ }^{2}$ roberto.kaban@yahoo.com
}

\begin{abstract}
Internet technology is no longer a sentence that is foreign to the people in the computer world, it is not surprising that so many we meet places to access the internet. Not only that, even in companies and educational environments have started to open the network to access the internet. As in the extra organizations that exist in the Campus Akademi Manajemen Informatika Komputer Medan Business Polytechnic (AMIK MBP) Medan which is a container of activities that accommodate the aspirations of students for the sake of education and cultivate the creativity of students in organizing through science activities, technology, sports, arts and culture. Accept the Internet becomes one of the most important needs in supporting organizational activities.

In the extracurricular organization of the campus AMIK MBP Medan still do by way of paper pamphlets attached to the existing mading on campus AMIK MBP Medan. When viewed in passing that has been used for things that are very good but besides that they do not use the internet, the internet when it is a means of promotion that can be used to provide better results from the previous system.

By using the Extracurricular Organizational Application, coverage will be more extensive and the resulting information will be more accurate. In terms of use of internet media as a means of information costs incurred more efficiently.
\end{abstract}

Keyword: Application, Organitation, Extracurricular, Application Extracurricular

\section{PENDAHULUAN}

Saat ini web tidak semata-mata digunakan untuk menampilkan informasi saja, namun fungsi web sudah semakin meluas. Antara sesama pemakai internet dapat berkomunikasi dengan cara mengirim dan menerima pesan. Selain itu fasilitas internet juga menyajikan file-file program secara gratis. Tentu saja hal ini menjadikan internet sebagai media dan sarana informasi yang tercepat saat ini bagi masyarakat.

Teknologi internet bukan lagi menjadi kalimat yang asing bagi orang yang berkecimpung di dunia komputer, tidak mengherankan jika banyak sekali kita jumpai tempat-tempat untuk mengakses internet. Bukan itu saja, bahkan di perusahaan dan lingkungan pendidikan sudah mulai membuka jaringan akses untuk layanan internet. Seperti halnya dalam organisasi ekstra yang ada di Kampus Akademi Manajemen Informatika Komputer Medan Business Polytechnic (AMIK MBP) Medan yang merupakan suatu wadah kemahasiswaan yang menampung aspirasi mahasiswa demi kemajuan pendidikan dan menumbuh kembangkan kreativitas mahasiswa dalam berorganisasi melalui kegiatan-kegiatan ilmu pengertahuan, teknologi, olahraga, seni dan budaya. Internet dirasakan menjadi salah satu kebutuhan yang sangat penting dalam menunjang kegiatan organisasi.

Dari penjabaran sebelumnya, maka dapat dibuat beberapa perumusan masalah sebagai berikut:

a. Bagaimana membuat sebuah sistem yang dapat memberikan informasi mengenai organisasi ekstra yang ada dikampus AMIK MBP Medan secara lengkap dan akurat.

b. Bagaimana membuat database sebagai media penyimpan data-data organisasi ekstra yang berisikan informasi.

c. Bagaimana membuat suatu pendataan yang lebih baik dan efektif dalam mendata organisasi serta kegiatan-kegiatan yang akan dilaksanakan maupun yang sudah terlaksana pada Kampus AMIK MBP Medan.

\section{METODE PENELITIAN}

Metode penelitian yang digunakan dalam menyelesaikan penelitian ini adalah sebagai berikut:

1. Analisa

Langkah ini merupakan analisa terhadap kebutuhan sistem. Pengumpulan data dalam tahap ini bisa malakukan sebuah penelitian, wawancara atau studi literatur. Seorang sistem analis akan menggali informasi sebanyak-banyaknya dari user sehingga akan tercipta sebuah sistem komputer yang bisa melakukan tugas-tugas yang diinginkan oleh user tersebut. Tahapan ini akan menghasilkan dokumen user requirment atau bisa dikatakan sebagai data yang berhubungan dengan keinginan user dalam pembuatan sistem. Dokumen ini lah yang akan menjadi acuan sistem analis untuk menterjemahkan ke dalam bahasa pemrograman. 


\section{Design}

Proses desain akan menerjemahkan syarat kebutuhan ke sebuah perancangan perangkat lunak yang dapat diperkirakan sebelum dibuat coding. Proses ini berfokus pada : struktur data, arsitektur perangkat lunak, representasi interface, dan detail (algoritma) prosedural. Tahapan ini akan menghasilkan dokumen yang disebut software requirment. Dokumen inilah yang akan digunakan proggrammer untuk melakukan aktivitas pembuatan sistemnya.

\section{Coding \& Testing}

Coding merupakan penerjemahan design dalam bahasa yang bisa dikenali oleh komputer. Dilakukan oleh programmer yang akan menerjemahkan transaksi yang diminta oleh user. Tahapan ini lah yang merupakan tahapan secara nyata dalam mengerjakan suatu sistem. Dalam artian penggunaan komputer akan dimaksimalkan dalam tahapan ini. Setelah pengkodean selesai maka akan dilakukan testing terhadap sistem yang telah dibuat tadi. Tujuan testing adalah menemukan kesalahan-kesalahan terhadap sistem tersebut dan kemudian bisa diperbaiki.

\section{Penerapan}

Tahapan ini bisa dikatakan final dalam pembuatan sebuah sistem. Setelah melakukan analisa, design dan pengkodean maka sistem yang sudah jadi akan digunakan oleh user.

\section{Pemeliharaan}

Perangkat lunak yang sudah disampaikan kepada pelanggan pasti akan mengalami perubahan. Perubahan tersebut bisa karena mengalami kesalahan karena perangkat lunak harus menyesuaikan dengan lingkungan (periperal atau sistem operasi baru) baru, atau karena pelanggan membutuhkan perkembangan fungsional.

\subsection{Analisa}

Aplikasi adalah suatu kelompok file form, class, report yang bertujuan untuk melakukan aktivitas tertentu yang saling terkait, misalnya aplikasi payroll,aplikasi fixed asset, dll. (Harip Santoso, 2010)

sistem merupakan sekumpulan objek-objek atau elemen-elemen yang saling berelasi dan berinteraksi, serta hubungan antara objek atau elemen bisa dilihat sebagai satu kesatuan yang dirancang untuk mencapai suatu tujuan.

Suatu sistem mempunyai karakteristik atau sifat-sifat yang tertentu, yaitu mempunyai komponenkomponen (components), komponen-komponen yang saling berhubungan (interrelated components), batas sistem (boundary), tujuan atau sasaran (purpose), lingkungan luar sistem (environment), penghubung (interfaces), batasan (constraints), masukan (input) dan keluaran (output).

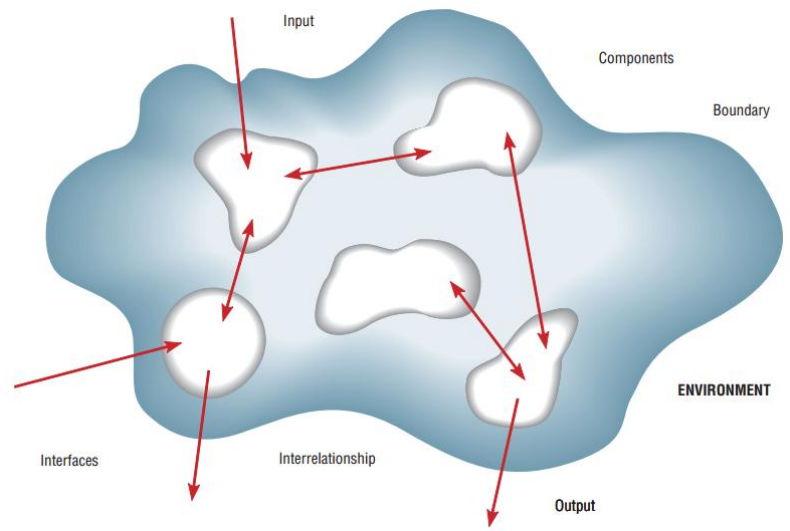

Gambar 2.1 Karakteristik Sistem

Berikut adalah penjelasan dari masing-masing karakteristik sistem:

1. Komponen (component)

Suatu sistem terdiri dari sejumlah komponen yang saling berinteraksi, yang artinya saling bekerja sama membentuk satu kesatuan. Komponenkomponen sistem atau elemen-elemen sistem dapat berupa suatu subsistem atau bagian-bagian dari sistem. Setiap sistem tidak peduli betapapun kecilnya, selalu mengandung komponen-komponen atau subsistem-subsistem.

2. Komponen yang saling berhubungan (Interrelated Components)

Ketergantungan salah satu bagian dari sistem terhadap satu bagian atau lebih sistem lainnya.

3. Batas sistem (boundary)

Batas sistem merupakan daerah yang membatasi antara suatu sistem dengan sistem yang lainnya atau dengan lingkungan luarnya.

4. Sasaran sistem (Purpose)

Suatu sistem pasti mempunyai tujuan (goal) atau sasaran (objective). Semua komponen sistem bekerja sama untuk mencapai tujuan, suatu sistem dikatakan berhasil bila mengenai sasaran atau tujuannya.

5. Lingkungan (environment)

Segala sesuatu di luar sistem, lingkungan yang menyediakan asumsi, kendala, dan input terhadap suatu sistem.

6. Penghubung (interface)

Tempat dimana komponen atau sistem dan lingkungannya bertemu atau berinteraksi.

7. Batasan (constraints)

Sebuah sistem harus memiliki batasan (seperti kapasitas, kecepatan atau kemampuan) terhadap apa yang ingin dicapai sebuah sistem.

8. Masukan (input)

Sumber daya (data, bahan baku, peralatan, energi) dari lingkungan yang diolah dan dimanipulasi oleh sebuah sistem.

9. Keluaran (output)

Sumber daya atau produk (informasi, laporan, dokumen, tampilan layer computer, barang jadi) 
ISSN: 2301-797X

Volume: 7 No. 1 - Mei 2018

yang disediakan untuk lingkungan sistem oleh kegiatan dalam suatu sistem. (Valacich et all, 2015:6)

\section{HASIL DAN PEMBAHASAN}

\subsection{Hasil Program}

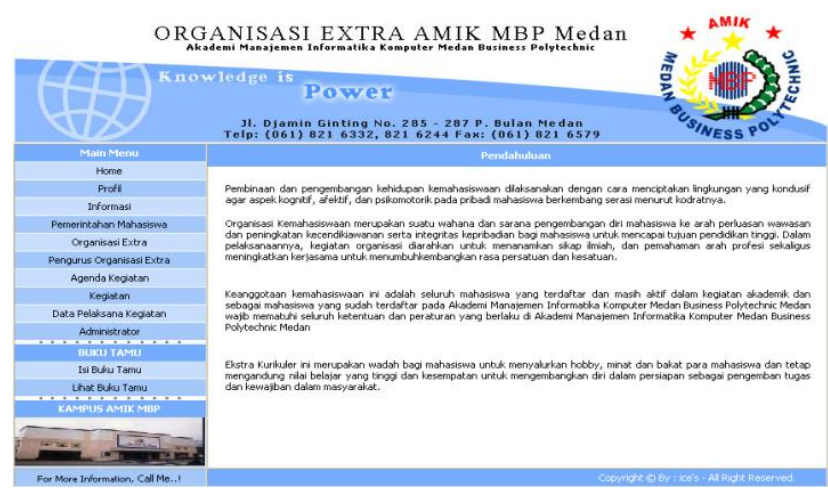

Gambar 3.1 Tampilan Hasil Program Menu Utama

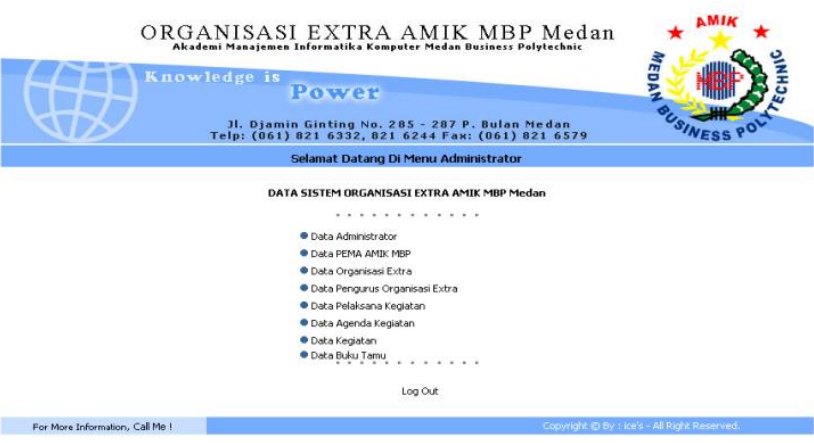

Gambar 3.2 Tampilan Hasil Program Menu Utama Admin

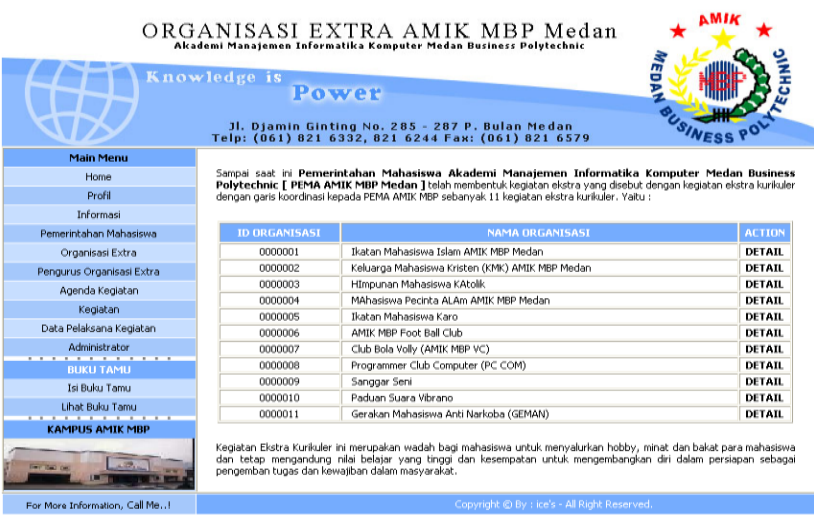

Gambar 3.3 Tampilan Hasil Program Menu Organisasi

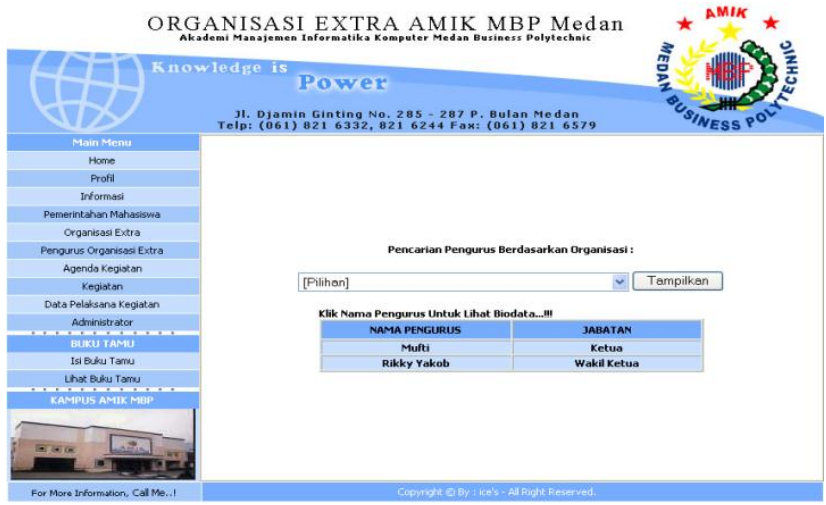

Gambar 3.4 Tampilan Hasil Program Pengurus Organisasi

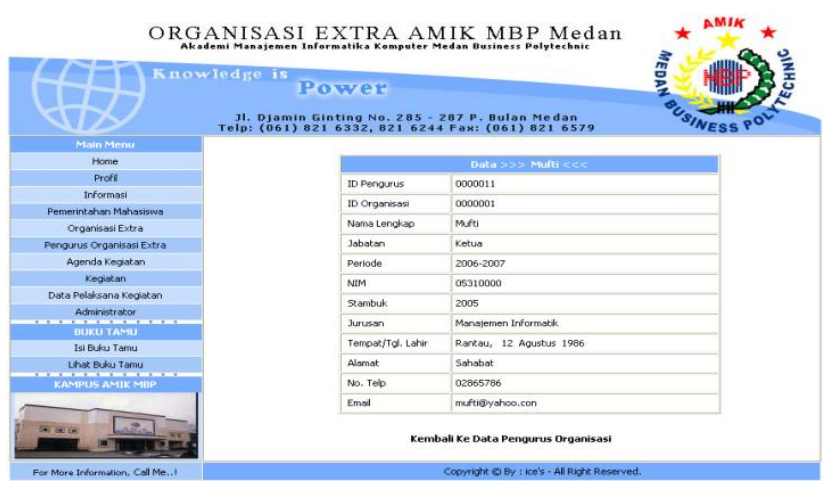

Gambar 3.5 Tampilan Hasil Program Pengurus Organisasi Detail

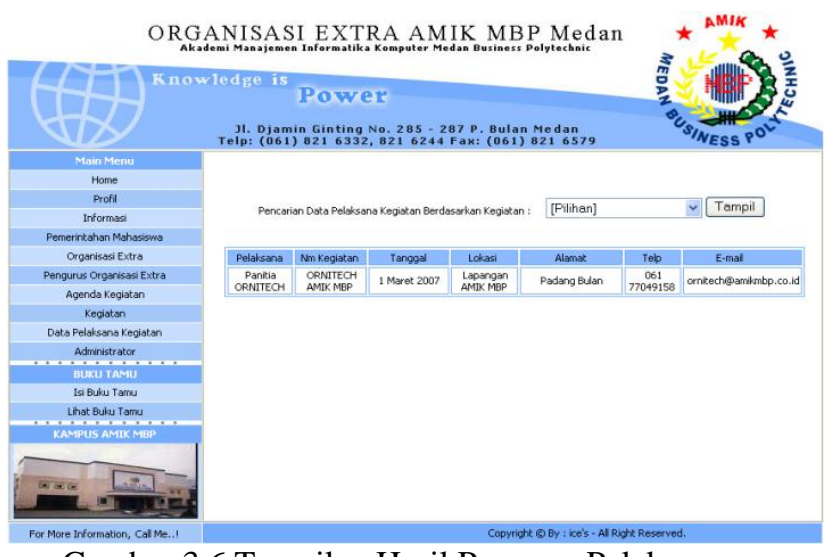

Gambar 3.6 Tampilan Hasil Program Pelaksana Kegiatan 
ISSN: 2301-797X

Volume: 7 No. 1 - Mei 2018

\subsection{Flowchart}

Flowchart atau diagram alir adalah sekumpulan simbol-simbol atau skema yang menunjukan atau menggambarkan rangkaian kegiatan program dari awal hingga akhir. Berikut adalah gambaran flowchart yang penulis buat, dimana flowchart tersebut disesuaikan dengan perancangan input output data dalam sistem yang dibuat.

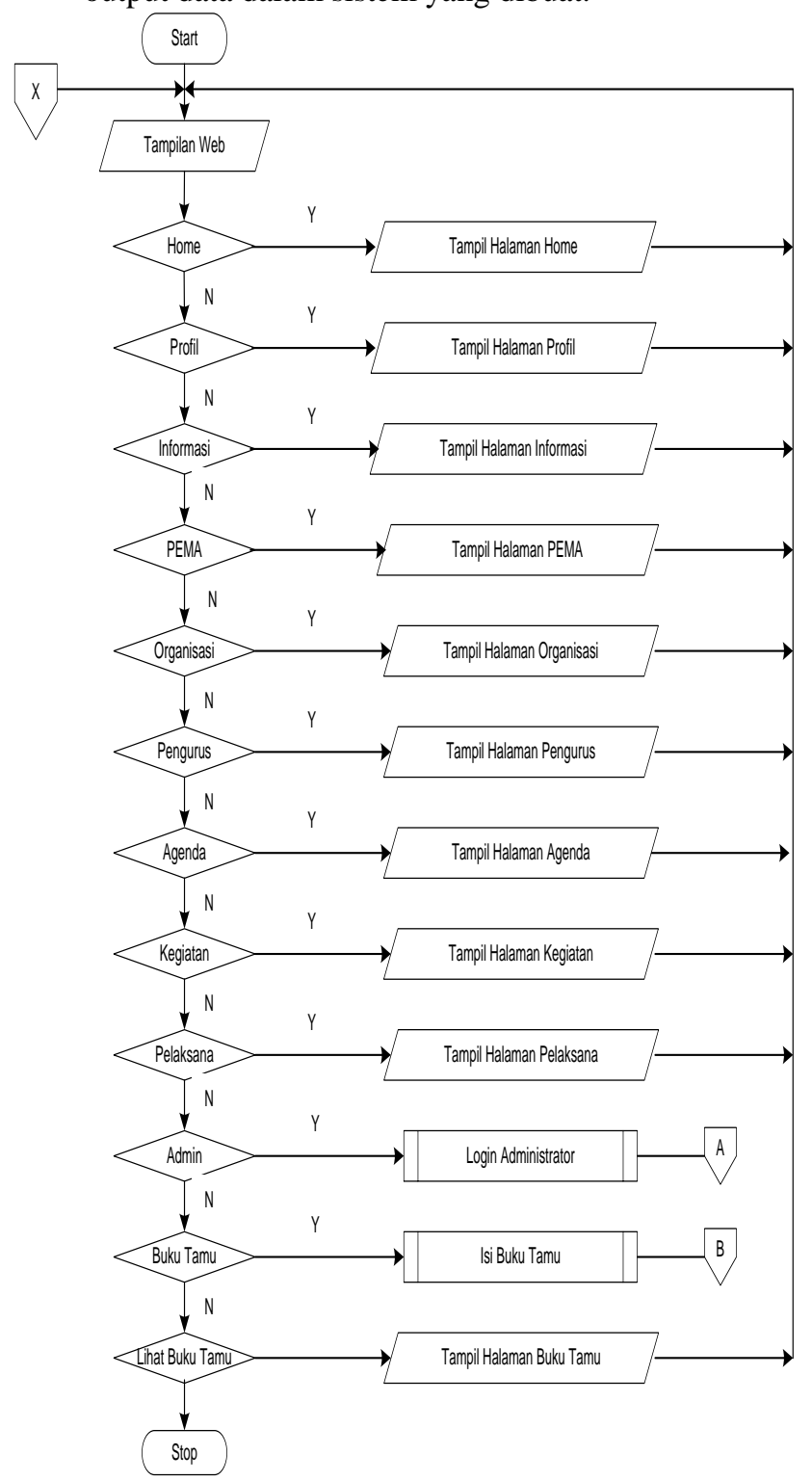

Gambar 3.7 Flowchart Menu Utama

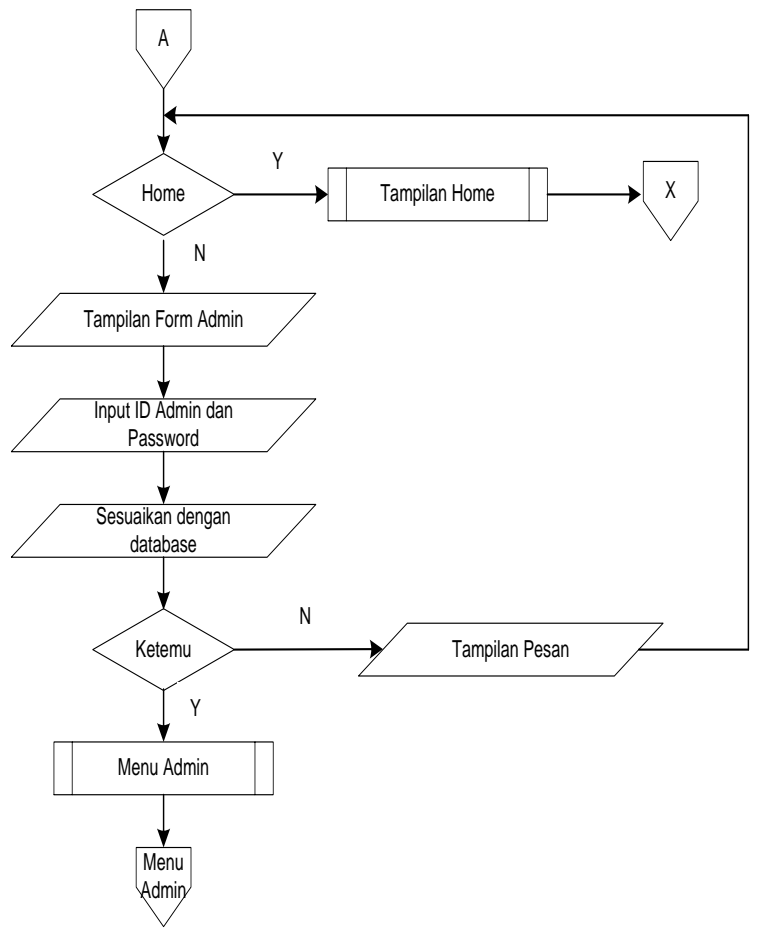

Gambar 3.8 Flowchart Login Admin

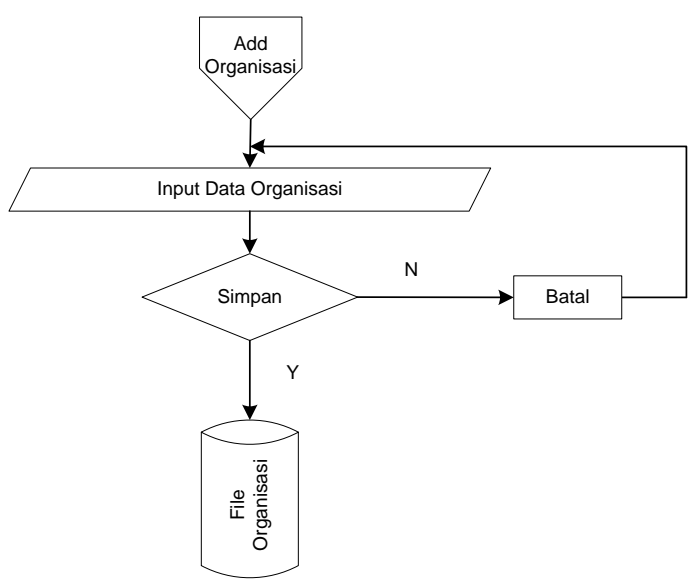

Gambar 3.9 Flowchart Input Data Organisasi 


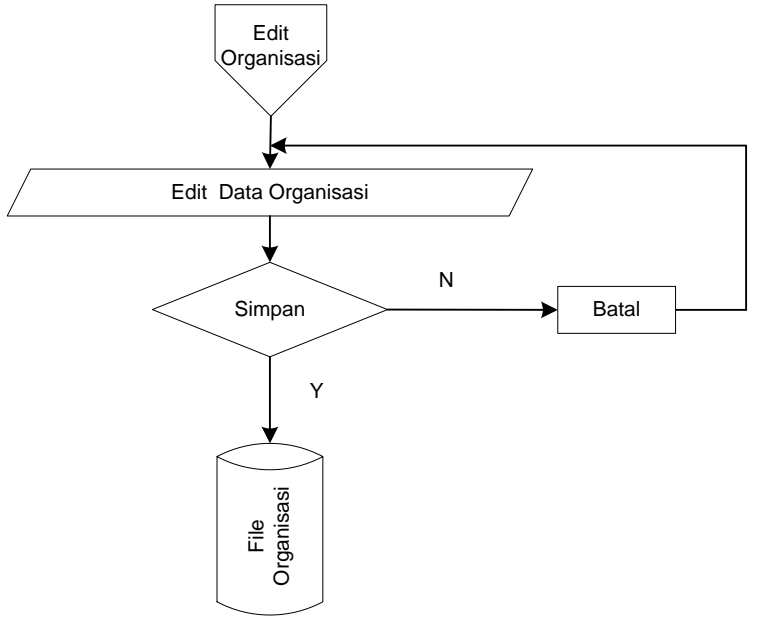

Gambar 3.10 Flowchart Edit Data Organisasi

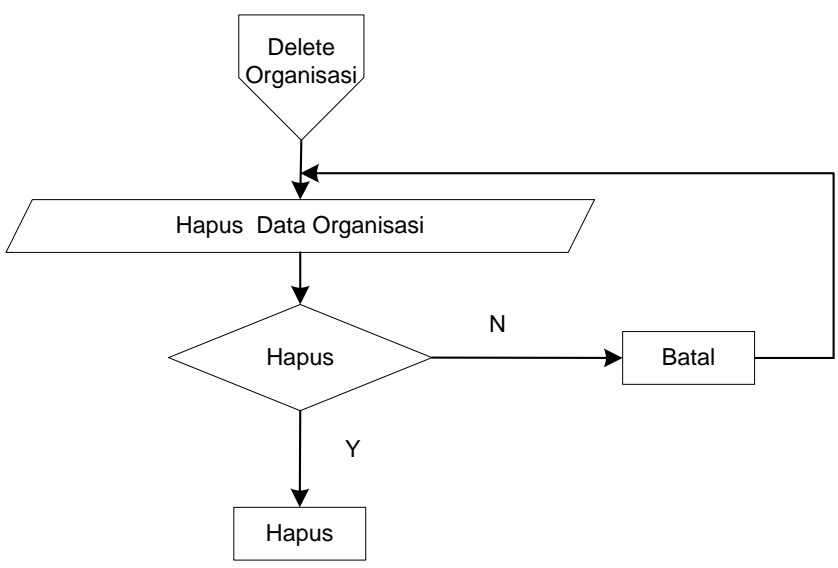

Gambar 3.11 Flowchart Hapus Data Organisasi

\subsection{Spesifikasi Program}

Spesifikasi program adalah menyangkut tentang penggunaan perangkat lunak (software), Perangkat keras (hardware) dan pemakai (user/brainware).

Penjelasan tentang mengenai masing-masing bagian tersebut (software, hardware, dan brainware atau user). Dapat dilihat sebagai berikut:

\section{Perangkat Lunak (Software)}

a. Dalam kesempatan ini penulis mengunakan Sistem Operasi Windows 7.

b. Xampp merupakan software yang digunakan untuk membangun sebuah PHP Server didalam Windows.

c. MySQL adalah multi user database dalam bahasa SQL (Structure Query Language).

d. HTML Editor adalah software yang dipakai untuk mendesain web seperti: Notepad, Macromedia Dreamweaver dan software lainnya.

e. Web server sebagai server local sebelum file-file dan script web dipublikasikan pada ISP (Internet Service Provider), yang disebut PWS (Personal Web Server ) atau Apache. f. Browser sebagai output atau tampilan hasil akhir program yang telah selesai, misal: Internet Explorer, Google Chrome, Opera,Mozilla Firefox dan lainnya.

2. Perangkat Keras (Hardware)

a. Minimal Microprosessor Pentium IV. Dalam kesempatan ini penulis menggunakan Intel Core i3.

b. Hardisk untuk sistem operasi dan sebagai tempat penyimpanan data. Dalam hal ini kapasitas hardisk dapat dikelompokkan menjadi dua bagian sesuai dengan seberapa besar data yang akan diolah dan disimpan yaitu : untuk client standard komputer pentium IV dengan hardisk 20 Giga Byte dan untuk server sebaiknya digunakan Pentium yang lebih tinggi dengan hardisk minimal 320 Giga Byte.

c. Memory standard 1 GB.

d. Monitor Super VGA 14',

e. Keyboard Windows.

f. Mouse (supaya lebih puas gunakan optik).

\section{Pengguna User (Brainware)}

Yaitu orang yang mengerti dan mampu menggunakan sistem windows dan internet

Dalam hal ini user dibagi menjadi 2 bagian yaitu:

a. Publikasi / pengunjung

b. Administrator / Programmer

\section{Prosedure Penggunaan Program (Manual)}

Adapun prosedure penggunaan program secara manual dapat diuraikan dengan jelas sebagai berikut:

1. Jalankan Aplikasi Xampp

2. Start Apache dan MySql.

3. Aktifkan Internet Explorer.

4. Ketik Address nya http://localhost/extra/ di Google Chrome kemudian enter

5. Setelah web terbuka dapat kita lihat halaman menu utama yang berisikan beberapa link yaitu: link profil, link informasi, link pemerintahan mahasiswa, link organisasi, link pengurus organisasi, link agenda kegiatan, link kegiatan, link pelaksana kegiatan dan link buku tamu.

6. Apabila kita ingin melihat halaman informasi maka kita klik link informasi ini biasanya dilakukan oleh siapa saja yang ingin mendapatkan informasi tentang kegiatan organisasi ekstra AMIK MBP Medan.

7. Apabila kita ingin melihat menu admin maka kita klik link menu admin maka kita dapat melihat beberapa menu dari admin dan untuk kembali ke menu sebelumnya klik link. Link ini hanya dapat dilakukan oleh orang-orang tertentu yang mengetahui kata kunci untuk pengisian atau pengeditan data-data yang ada di menu administrator. 
8. Setelah selesai klik tombol close [ X ] pada layar untuk menutup website dan kembali ke windows explorer.

\section{KESIMPULAN}

Sebagai kesimpulan yang dapat diambil selama penulis menyusun penelitian ini sebagai berikut:

1. Didalam menginformasikan organisasi ekstra pada kampus AMIK MBP Medan masih melakukan dengan cara selebaran kertas yang ditempelkan pada mading yang ada pada kampus AMIK MBP Medan. Bila ditinjau sepintas semua usaha yang dilakukan sudah termasuk hal yang sangat baik tetapi disamping itu mereka tidak memanfaatkan jasa layanan internet, padahal internet merupakan sarana promosi yang dapat digunakan sehingga dapat memberikan hasil yang lebih baik dari sistem yang digunakan sebelumnya.

2. Dengan menggunakan Aplikasi Pengelolaan Organisasi Ekstrakurikuler daya jangkau akan semakin luas dan informasi yang dihasilkan akan lebih akurat.

3. Ditinjau dari segi ekonomisnya penggunaan media internet sebagai sarana informasi biaya yang dikeluarkan semakin efisien.

\section{DAFTAR PUSTAKA}

Anastasia,M.M., 2013, “Trik Menguasai PHP + jQuery Berbasis Linux \& Windows”, Penerbit Lokomedia, Yogyakarta.

Brookshear, J.G, 2012, "Computer Science", 11 Edition, Pearson Education, Inc., Boston, Massachusetts.

Fathansyah, 2012, “Basis Data”, Cetakan Pertama (edisi revisi), Penerbit Informatika Bandung.

Kendall, K.E. dan Kendall, J.E. 2011, "System Analysis and Design Eighth Edition", Pearson Education, Inc., publishing as Prentice Hall, New Jersey.

Kristanto, A., 2010, “Kupas Tuntas PHP \& MySql”, Penerbit Cable Book, Klaten.

Kusnadi, Moh., 2011, "Kamus Pintar Komputer Dan Internet", Bintang Usaha Jaya, Surabaya.

Laudon, K.C. \& Laudon, J.P., 2012. "Management Information Systems Managing the Digital Firm 12 ${ }^{\text {th }}$, Pearson Prentice Hall, New Jersey USA.

Nana S.S., 2010, Metode Penelitian Pendidikan, Atas kerjasama Program Pascasarjana Universitas Pendidikan Indonesia dengan PT. Remaja Rosdakarya, Bandung.

Noor, J., 2011, "Metodologi Penelitian: Skripsi, Tesism Disertasi dan Karya Ilimiah”, Prenada Media Group, Jakarta.

Pratama, I.P.A.E., 2014, "Sistem Informasi dan Implementasinya”, Edisi Pertama, Penerbit Informatika Bandung
Schneider, G.P., 2011, "Electronic Commerce Ninth Edition", Course Technology, Cengage Learning, Boston, Massachusetts.

Shelly dan Rosenblatt, 2012, "System Analysis and Design, Ninth Edition", Course Technology, USA.

Sugiyono, 2009, Metodologi Penelitian Pendidikan, Pendekatan Kuantitatif, Kualitatif, dan $R \& D$, Alfabeta, Bandung.

Sukmadinata, NS., 2010, "Metode Penelitian Pendidikan", Penerbit PT. Remaja Rosdakarya, Bandung.

Valacich, et all, 2015, "Essentials of Systems Analysis and Design, Edisi Keenam, Pearson Education Limited, England.

Whitten \& Bentley, 2007, "Systems Analysis \& Design Methods 7th Ed.", McGraw-Hill Irwin, New York. 